\title{
THE ROLE OF TRANSPORT IN EUROPEAN TOURISM FLOWS
}

Géza Tóth, Lóránt Dénes Dávid, László Vasa

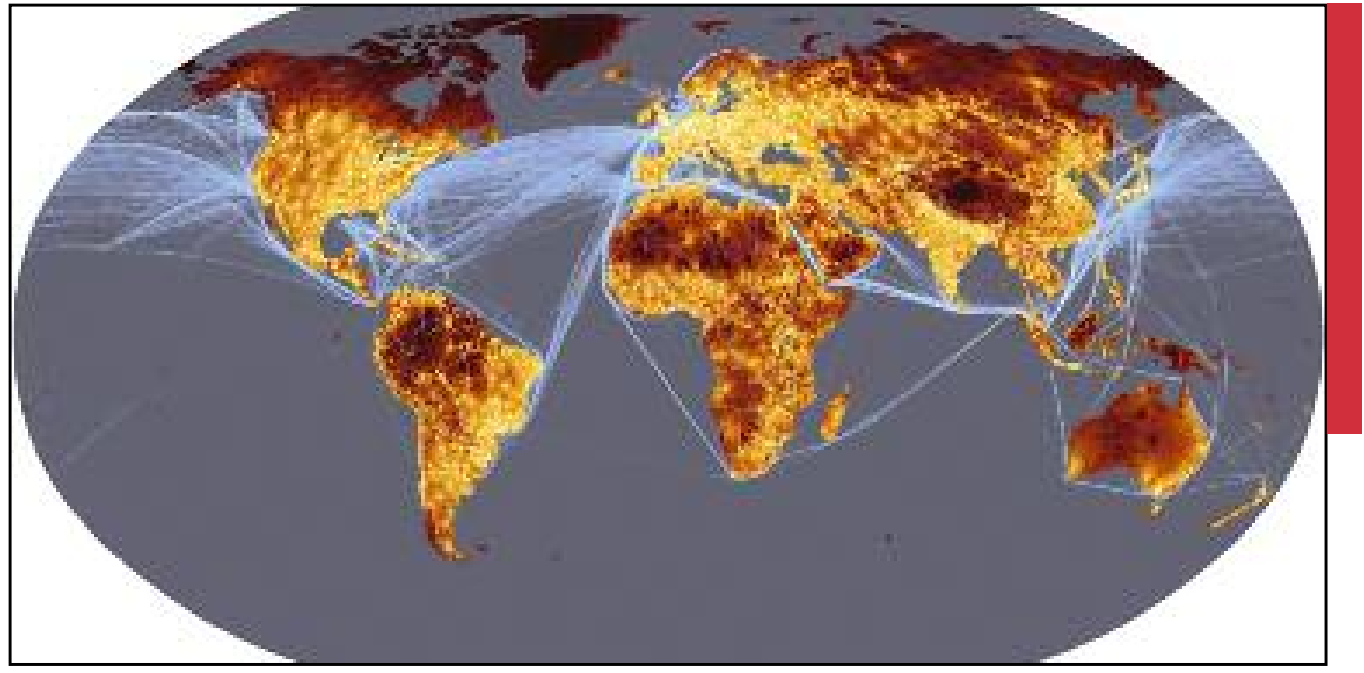

A global map of Accessibility

(source: http://bioval.jrc.ec.europa.eu/products/gam/index.htm) 


\section{The role of transport in European tourism flows}

DOI: http://dx.doi.org/10.3986/AGS54205

UDC: $911.3: 338.48(4)$

338.48:656(4)

COBISS: 1.01

ABSTRACT: This study aims at investigating the multiple and complex relationships between transport and tourism by various methods. In this paper, spatial interaction model and the shift-share analysis are used in different approaches. Factors of the relationship between the transport distance and tourism intensity will be detected and the connections between the accessibility of European regions and their tourism will be analysed. One of the major questions of our study is if there is any relationship between transport and tourism at European regional level (NUTS2); and if so, is there any kind of regularity in the relationship, as Bull (1994) states in his study. Finally, we examined whether there are any differences in this relationship at the level of the European regions.

KEY WORDS: geography, tourism, tourism flows, accessibility, modelling

The article was submitted for publication on November 5, 2012.

ADDRESSES:

Géza Tóth, Ph. D.

Hungarian Central Statistical Office

5-7. Keleti K. str., Budapest, Hungary

E-mail: geza.toth@ksh.hu

Lóránt Dénes Dávid, Ph. D.

Eszterházy Károly University College

1. Eszterházy square, Eger, Hungary

E-mail: david.lorant@ektf.hu

SAPIENTIA - Hungarian University of Transylvania

1 Libertatii Square, 530104 Miercurea Ciuc, Harghita County, Romania

László Vasa, Ph. D.

Szent István University

1. Páter Károly str., Gödöllő, Hungary

E-mail:Vasa.Laszlo@gtk.szie.hu 


\section{Introduction}

The relationship between tourism and transport has been the focal point of studies for a long period of time (Hall 2010). The matter covers questions whether such a relationship between the two activities can be measured at all, along with additional ones regarding the closeness and strength of the relationship if it exists. It is also relevant to study if such a relationship is observable in general, or with detectable, significant spatial disparities, which is the particular subject this paper intends to investigate.

According to our initial hypothesis, although tourism performance is greatly impacted by the level of service provided by transport, related spatial disparities also play a significant role in forming it.

\section{Objectives}

Prior to its launch, the research intended to focus on performing a general investigation of the relationship between transport distance and tourism on the example of the European regions, as well as to study the role of distance and accessibility as relevant to the topic in order to point out the significance and spatial aspects of this topic.

First of all, it is important to claim that we intend to study the relationship between tourism and transport in general, along with an approach by which the spatial movements of individuals, including tourists, become more apprehensible.

\section{Literature review}

The role of transport is manifested in connecting tourism demand and supply and in the internal features of supply, i.e. the destination to be accessed. Transport is one of the primary preconditions to the existence of tourism (Topole 2009, Todorovic and Bjeljac 2009). It is a key element that links tourists to destinations to be accessed. Though the connection between tourism and transport has been widely examined previously (Page 2005; Prideaux 1993), there are still significant gaps in this research topic (Chew 1987; Gunn 1994; Hall 1991; Inskeep 1991; Page 1994; Page 1999; Robbins and Thompson 2007). As pointed out by Knowles (1993), in many cases researchers took transport into account as a passive element in tourism, not as an integral part of tourism activities. Though the tourism product to be consumed by tourists, i.e. the set of services (accommodation, catering, entertainment and other services) is based on attractions accordant with the motivation of tourists, it also includes transport.

During travels, travellers get from generating regions through transit regions to destination regions. Generating, transit and destination regions were distinguished by Pearce (1989) after Thurot (1980) while studying the impacts of tourism. For transit regions, the character and capacity of transport networks were studied with their limitations pointed out.

\section{Tourism and accessibility}

Definitions for accessibility were often developed as an establishment of a spatial model or calculation. Thus a more detailed analysis into the topic, pointing out the wide range of compounds that the relationship between accessibility and tourism is dependent upon, is thought to be more expedient. Such approach is reflected by the definition according to which accessibility can be regarded: the sustainability potential of the built environment and the dimension of mankind's quality of life; thus it is basically an approach of how the relative importance of certain spatial points are judged (Makri 2001).

The content behind the definition of accessibility can certainly be modelled in various ways. However, in our study several examples were applied for quantification of the basic definition, and the same contextual frame was studied. 


\section{A research into the European tourism flows}

Transport distance as one of the substantial indicators of travel is only one among the selection criteria of destinations. Regarding distance, a different overall view is drawn for movements for leisure purposes when compared to all dislocations. According to Bull (1994), the travel intensities with shortening distances will increase to a certain position followed by a decline and finally, a zero travel intensity observed at zero distance. At the root of this is the fact that too nearby, thus too quickly accessible destinations are not attractive for visitors as they are considered to be part of their everyday milieu.

It can also be concluded that several tourist destinations indicate a rather intensive development despite their locations relatively distant to their competitors. In many cases, poor accessibility can be practically balanced by other factors of attraction such as a destination where attraction is represented by unfavourable accessibility, for example a remote, wild destination.

As revealed by certain studies, accessibility has a role primarily in selecting tourist destinations (Thompson and Schofield 2007). Tourism in easily accessible towns indicates intensive development as opposed to those hard-to-access stagnates. According to a hypothesis, tourists during their travel decisions select the destinations to be reached first based on the local possibilities and attractions (Crompton 1992). In this decision-making, destinations sufficing the purposes of visitors and with similar type of endowments are taken into account (Celata 2007). Only after this primary selection is made will destinations be compared by accessibility. Thus accessibility primarily has or can theoretically have a role in substituting potentially visitable destinations. On the contrary, destinations capable of providing comparative advantages for tourists can attract a significant number of visitors even if with relatively unfavourable accessibility. Consequently, the matter of accessibility is relevant for destinations with similar endowments (seaside), whereas it is less remarkable for those with individual attractions (historical towns, spas). Favourable accessibility itself does not necessarily represent an origin of competitiveness.

Fotheringham $(1983,1984,1991)$ developed a spatial interaction model of competing destinations that is basically a single limited accessibility model by which we first intend to analyse the relationship between accessibility and tourism. Accordingly:

$$
I_{i j}=\left[O_{i} S_{j} D_{i j} A_{j}\right]
$$

where $\mathrm{I}_{\mathrm{ij}}$ is the interaction between the $\mathrm{i}^{\text {th }}$ origin and the $\mathrm{j}^{\text {th }}$ destination, $\mathrm{O}_{\mathrm{i}}$ is the $\mathrm{i}^{\text {th }}$ place's ability as an origin to contribute to the interaction, $S_{j}$ is the attractiveness of $j$ as a destination, $D_{i j}$ is the intervening distance between the origin and destination, and $\mathrm{A}_{j}$ is the competing destinations variable being the accessibility of $j^{\text {th }}$ destination relative to all others that may interact with the $i^{\text {th }}$ origin, i.e.:

$$
A j=\sum_{\substack{k=1 \\ k \neq j}}^{m} S_{i} D_{i j}
$$

We presumed that the number of guest nights in a given region depends on the effective demand of a potential sending region, the attractiveness of the destination, the distance between the sending and receiving regions, as well as on the competition between the two areas. These factors have been included in our model.

Hereafter, the research attempts to focus on the type of relationship explored between theoretical accessibility calculated for tourism and statistical data on the number of visitors.

The starting point of our study, for practical reasons, was the European Union's NUTS system as it is ensured that data is available at comparable regional levels. For the calculations, NUTS2 data was used. The number of regions considered was 280 with transcontinental areas of France, Spain and Portugal excluded.

In the model, the universal accessibility definition was applied, i.e. given regions were not analysed by their main generating regions. In other words, theoretically, travels can be made from any region to any other one with tourist motivation (obviously, in practice, this is not the case; however, due to the features of modelling, it was put aside).

The participatory capacity of departure regions in the interaction was attempted to be quantified by their population data. 
The tourist attraction of destinations was represented by the number of beds in hotel type units in the given region. We claim by this that the bulk of attraction is indicated directly as, not regardless to the general level of economic development and processes, the greater the attraction, the more beds there are at quarters.

Distance between the origin and destination regions was specified by the distance between the regional centres, by road, measured in minutes. Applying road distance data is apparently the first approach only as being otherwise obvious; other transport sub-sectors also play a relevant role in tourism-induced travels in the study regions. The number of guests in a given region, i.e. in this particular case, the number of guest nights can be calculated as the sum of incoming tourism flows.

The spatial interaction model is based on a gravitational analogy as field intensity here is also studied in the relation of masses and distances. Our research intends to focus on the second one, i.e. the topic of accessibility. To estimate the role of distance sensitivity in tourism flows, an analysis on the value $\gamma$ constant can bind in the gravity model was relevant, i.e. at what power value the distance between the regions is taken into account. Therefore calculations were performed by constants within the range between 0 and 2 followed by studying the strength of correlation between the calculated and actual values.

As concluded by Dusek (2003) in his work on the gravity model: »With the exponent increasing, the intensity of interregional connections becomes more distance sensible and collaterally the relevance of masses will gradually decline."

Table 1: Weighted means of the Pearson correlation coefficients for various $\gamma$ constants of the gravity model.

\begin{tabular}{llllll}
\hline Gravity $(\gamma)$ & 0.0 & 0.5 & 1.0 & 1.5 & 2.0 \\
\hline Weighted mean of Pearson correlation coefficient $(r)$ & 0.87 & 0.85 & 0.71 & 0.49 & 0.25 \\
\hline
\end{tabular}

Source: own calculation.

By applying the spatial interaction model (Table 1), data on the number of guests can be sufficiently estimated. Therefore there is a relatively close connection between the interaction ability of the starting area, the attraction of the destinations, and the turnover estimated on the basis of destination competition and the actual number of guest nights. However, in this case the distance is calculated at the power of zero (which, in practice, means one between any points), which indicates that tourist flows are not distance dependent at European level! This is due to several reasons. On the one hand, the most important tourist destinations are located at the continent's periphery, at positions relatively disadvantageous from the point of view of accessibility. On the other hand, tourism product as a tourism experience is indefinable, i.e. one-time and perishing; can not be stored. E.g. in case somebody intends to spend the summer holidays at the seaside, such demand will not be replaced by spending it at a nearby, although well accessible, mountainous area, but will undertake travelling to remote peripheries.

\section{A study into accessibility and the number of guests by applying shift-share analysis}

The following analysis intends to study the extent of the number of guests in European regions explained by accessibility and other local reasons. To this, the shift-share analysis was applied. Description on the method has been given in several spatial statistical publications and volumes (Houston 1967; Curtis 1972; Berzeg 1978; Stevens and Craig 1980) and an example for its application regarding accessibility in Hungary was provided by Tóth (2002).

Here, thus, a different approach was attempted. As already indicated earlier, accessibility has or can have a role primarily in substituting potentially visitable destinations (Celata 2007). Obviously, the question can be raised whether this is the case for all destination groups.

Therefore destinations with similar features were intended to be studied from the aspect of accessibility. European regions were classified into five groups based on the location of the countries involved. Our hypothesis in this respect was that for the contiguous groups of countries, several differences can be observed regarding the type and strength of relationship between accessibility and the number of guests. 
It is possible to formulate groups in a number of ways. Our purpose was to place countries of very similar culture and tourism characteristics into the same groups. Group formation is naturally subjective nevertheless it can be done for the sake of the survey. The groups and the countries included can be seen on Figure 1.

Accessibility in this respect was studied not only based on road transport data but also multimodal accessibility, i.e. based on the use of various modes of conveyance and taking them into account collectively was attempted to be applied.

To this, data available on the Espon website (Internet 2) was used. The EPSON database we use represents outstanding standards in European regional studies because such a detailed, comprehensive, multi-modal accessibility database is believed to have been established only in the context of this research in cooperation with one of the most distinguished research groups in this field, the Spiekermann \& Wegener Urban and Regional Research.

Downloadable data, among others, included multimodal accessibility of NUTS3 regions in the study area. As our research was intended to be carried out at NUTS2 level, such data was inappropriate thus a population-weighted mean was applied.

The method of shift-share analysis is essentially a double standardization, which needs data by at least two structural - territorial and sector - dimensions. Sector indications actually may cover optional disjunctive distributions: economic sectors, age groups, and settlement size groups. Now we divided the regions under the level of their accessibility into groups. The territorial dimension may also have subgroups: e.g. settlements, regions, countries, groups of countries as it was seen earlier. Concerning certain phenomena, chronological growth components may be analysed just as differentiated structural patterns (e.g. per inhabitant guest nights).

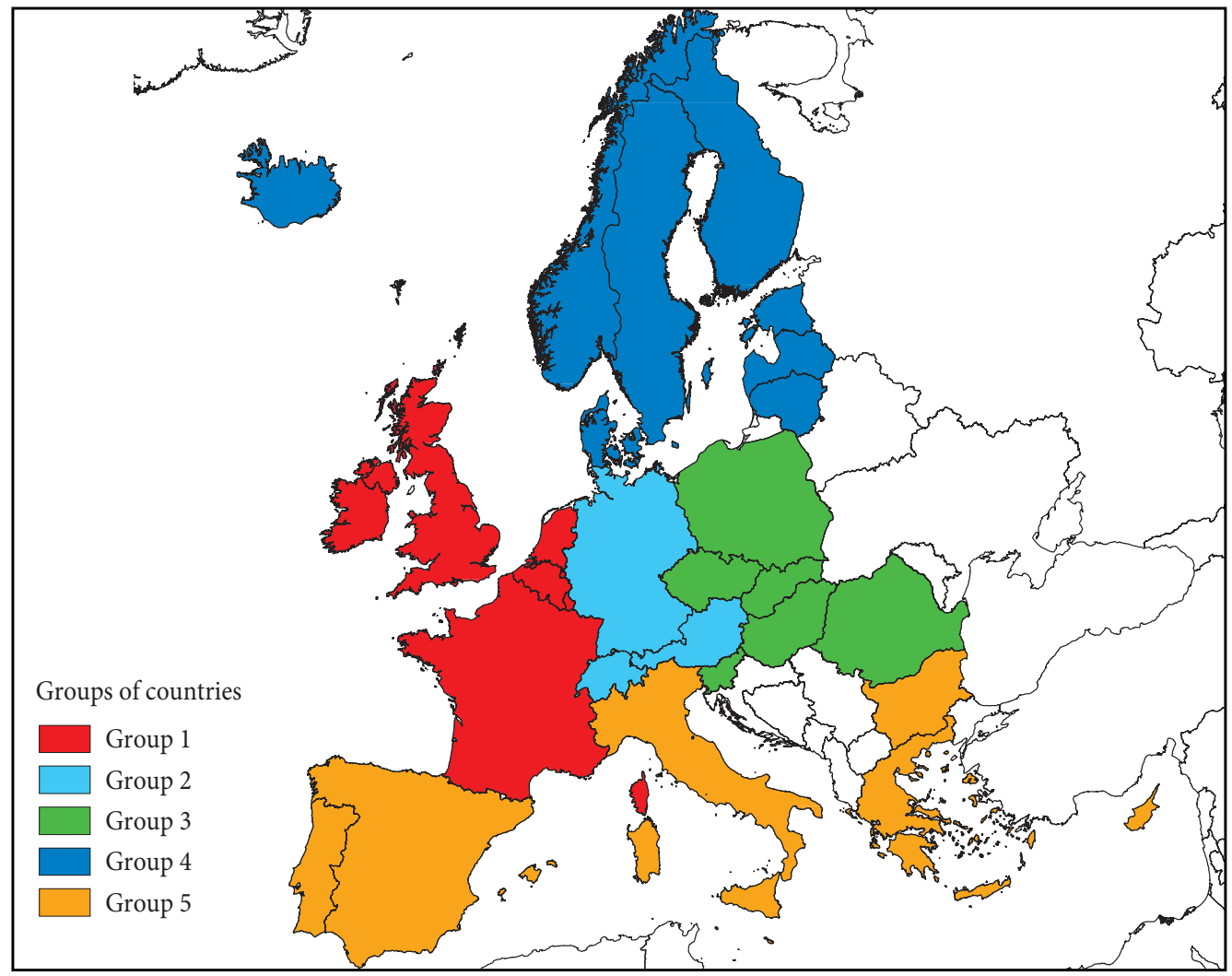

Figure 1: The groups of European countries. 
This research applies both types. First, changes in the number of guest nights were analysed between 2003 and 2009. In the second study, the specific method of shift-share analysis with the spatial disparities of guest nights per bed in 2009 factorised was applied. We intended to explore the amplitude accessibility and other local factors which are responsible for spatial disparities. (It is not possible to define the influencing specific local factors by the analysis, only the extent changes in the number of guests nights deviating from the European average is influenced by accessibility (in other words, the extent positive or negative deviation or in short surplus or deficiency in the number of guest nights compared to the average in the number of guest nights is entailed), and other factors characteristic for the given region (including: the level of urbanisation, seaside or mountain location etc.).

Table 2: Surplus/deficiency in the number of guest nights and its components, 2003/2009 in percent.

\begin{tabular}{lccc}
\hline Regions & Total & \multicolumn{2}{c}{ dimension } \\
\cline { 3 - 4 } & & Spatial & Accessibility \\
\hline Western Europe & 100 & -69 & 169 \\
West Central Europe & 100 & $-6,703$ & 6,803 \\
East Central Europe & -100 & 136 & -236 \\
Northern Europe & -100 & -56 & -44 \\
Southern Europe & 100 & 226 & -126 \\
\hline
\end{tabular}

Source: own calculation.

In all the columns of the table the value is $100 \%$ if in the given region the number of guest nights grew faster than the European average and $-100 \%$ if the growth was slower. The spatial and accessibility columns present the components, i.e. to what extent the faster or slower than average growth in guest nights is the result of accessibility or other unconnected local reasons. Local reason may be utterly diverse in this respect. Both subjective factors (milieu, image) and objective ones (quality and price of services) can be taken into consideration.

As indicated by the data in Tables 2 and Figure 2, accessibility plays a more important role in the changes in the number of guest nights than spatial dimensions, i.e. other local conditions for 3 of the 5 groups of countries as having higher absolute values. It is due to their accessibility position that Western and West Central Europe have more advantageous trends whereas countries in East Central Europe show slower dynamics compared to the European average - also primarily due to their accessibility. Disadvantageous accessibility further spoils disadvantageous local conditions in Northern Europe, while regarding the countries in Southern Europe, accessibility can slightly worsen favourable local endowments. Accessibility of Southern Europe can not be disadvantageous within the continent to impede the increase in the number of guests exceeding the European average. Table 3 indicates the components of changes in the number of guest nights between 2003 and 2009. It is clearly visible that during the indicated period more than two-thirds of the growth of guest nights was realised in Southern European regions while decrease was recorded mainly in West Central Europe in which case it can be stated that it is exactly where the negative spatial effects are concentrated. In spite of this, the latter could not hinder the former to a great extent and so higher than average growth in guest nights was achieved - compared to European average - in the region. The growth of guest nights was slower than the European average in East Central Europe which includes Slovenia, although this negative tendency is dwarfed by the related data of Northern Europe. The main reason for slower growth of guest nights is the accessibility of the regions since there is a positive spatial factor in this region. The role of the two components in the development of the situation is not significant at a European scale, a fact supported by the relatively low percentage values of the region.

Regarding the factorisation of data of guest nights per bed in 2009 , a somewhat different overall view is seen (Table 3 and Figure 3). In all the columns, groups of regions achieved 100\% where the number of relative guest nights was higher than the European average and $-100 \%$ where it was lower. In this respect, one can observe a more important role of accessibility only for the West Central European countries compared to local conditions for the number of guest nights per bed. For the other groups of countries, however, it can be seen that conditions basically determined by local endowments can only be modified either in a positive or negative way by accessibility. 


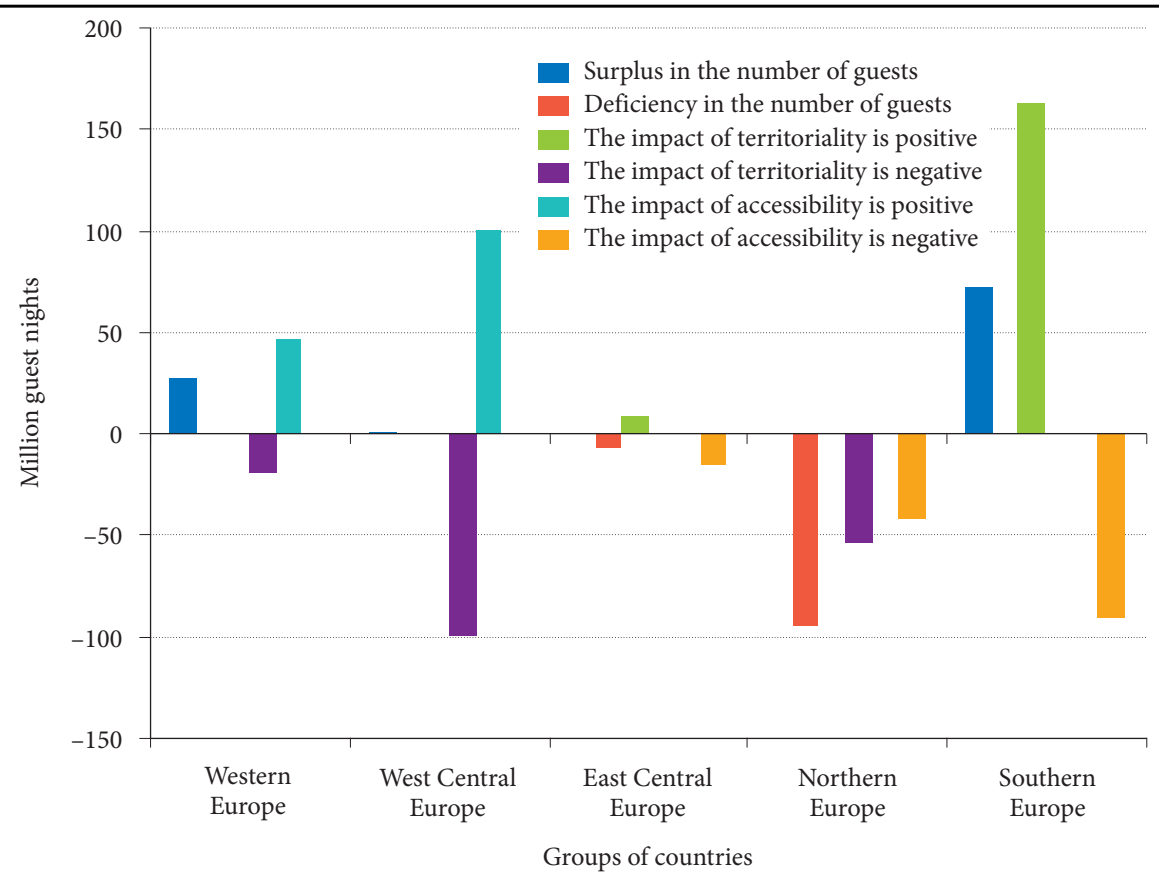

Figure 2: Share of regions in surplus/deficiency in the number of guest nights and its components, 2003/2009 in million guest nights. Source: own calculation.

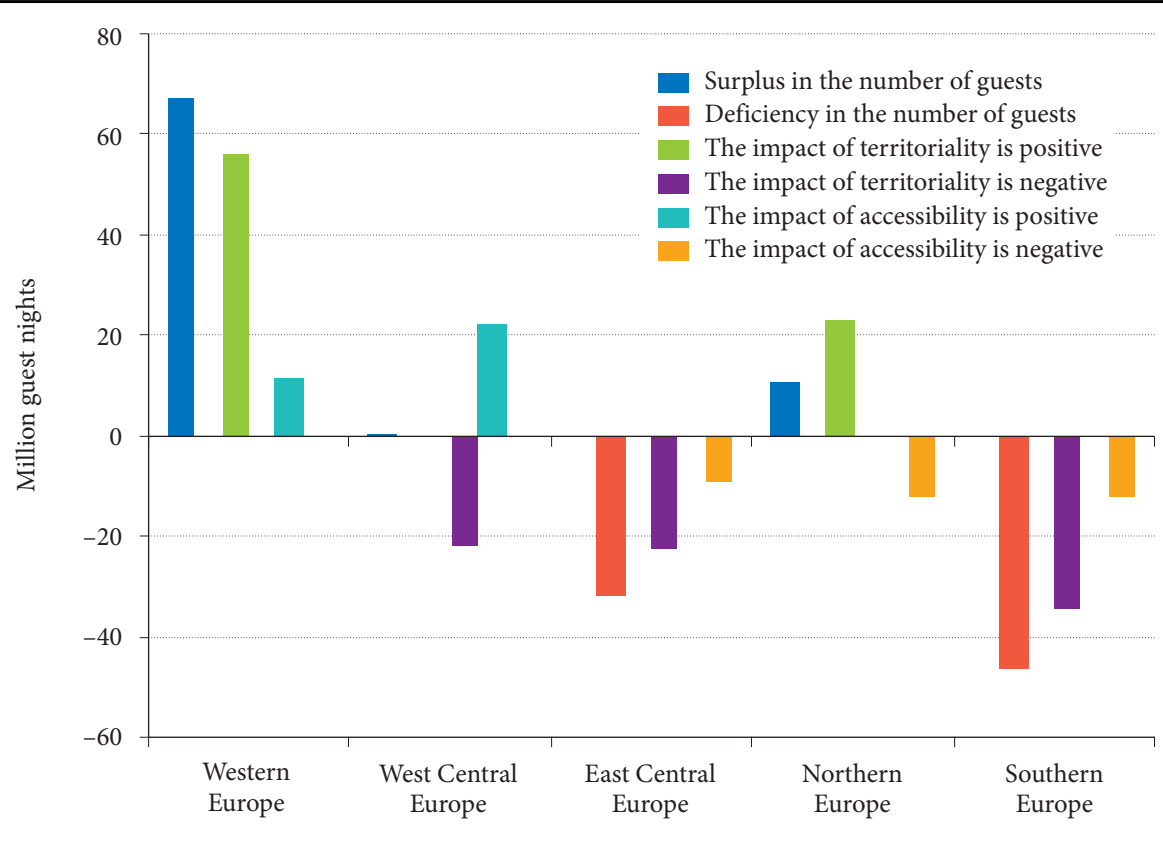

Groups of countries

Figure 3: Share of regions in surplus/deficiency in the number of guest nights and its components, 2009. 
Summarised, while accessibility plays a significant role in the changes in the number of guest nights in yet more groups of countries, its role in effectiveness is not relevant.

Table 3: Surplus/deficiency in the number of guests and its components, 2009 (in percent).

\begin{tabular}{lccc}
\hline Regions & Total & \multicolumn{2}{c}{ dimension } \\
\cline { 3 - 4 } & & Spatial & Accessibility \\
\hline Western Europe & 100 & 83 & 17 \\
West Central Europe & 100 & $-8,804$ & 8,904 \\
East Central Europe & -100 & -71 & -29 \\
Northern Europe & 100 & 216 & -116 \\
Southern Europe & -100 & -74 & -26 \\
\hline
\end{tabular}

Source: own calculation.

\section{Conclusions}

Based on the research carried out, it was concluded that the spatial interaction model is adequately suitable to estimate data on the number of guests; i.e. 3 of the 4 elements included in the model have a determining role in the development of level of guest nights. This is not the case considering the $4^{\text {th }}$ element, namely accessibility, since the model produced the most accurate result when distance was raised to power zero; therefore European tourist flows cannot be seen as distance dependent. With the results recognised, we argue the estimates on the relationship between the intensity of travels (that was modelled by the number of guest nights) and distance acknowledged (Bull 1994). This also means that there is no detectable link between the reductions of travel distances and travel intensity!

The results of the shift-share analysis carried out indicated that accessibility is playing a more important role than spatial dimension for 3 of the 5 groups of countries, as other local reasons. Regarding the data of guest nights per bed in 2009 (which we considered efficiency), a more important role of accessibility is observed exclusively for West Central European countries compared to local conditions. In other words, conditions determined by basically local endowments can only be modified by accessibility. Therefore, while accessibility plays a significant role in the changes regarding the number of guests still in more groups of countries, its role in effectiveness is not relevant. According to our relevant hypothesis regarding the relationship between accessibility and tourism, the fact that a significant difference exists was proved true.

All things considered, the role of accessibility is an important factor for many groups of countries from the point of view of changes in guest nights; however, its role is not proved by static testing of the effectiveness of tourism.

The estimate conceptualised in the null-hypotheses, according to which transport impacts tourism productivity, was proved true. Although the type and strength of relationship between tourism productivity and the level of services provided by transport can vary in different regions, we claim that the matter is worth paying attention to in the field of tourism planning.

\section{Acknowledgement}

The research was supported by the János Bolyai Research Scholarship of the Hungarian Academy of Sciences.

\section{References}

Berzeg, K. 1978: The empirical content of shift-share analysis. Journal of Regional Science 18-3. Columbus. DOI: http://dx.doi.org/10.1111/j.1467-9787.1978.tb00563.x

Bull, A. 1994: The Economics of travel and tourism. Pitman Publishing Melbourne.

Celata F. 2007: Geographic marginality, transport accessibility and tourism development. Global Tourism and regional competitiveness. Bologna. 
Chew, J. 1987: Transport and tourism in the year 2000. Tourism management 8-2. DOI: http://dx.doi.org/ 10.1016/0261-5177(87)90003-3.

Crompton, J. L. 1992: Structure of vacation destination choice sets. Annals of tourism research 19-3. DOI: http://dx.doi.org/10.1016/0160-7383(92)90128-C

Curtis, W. C. 1972: Shift-share analysis as a technique in rural development research. American journal of agricultural economics 54-2, Oxford.

Dusek, T. 2003: A gravitációs modell és a gravitációs törvény összehasonlítása. Tér és Társadalom 17-1. Budapest.

Fotheringham, A.S 1984: Spatial flows and spatial patterns. Environment and planning A 16-4. DOI: http://dx.doi.org/10.1068/a160529 London.

Fotheringham, A. S. 1991: Migration and spatial structure: The development of the competing the destinations model. Migration models: macro and micro approaches. London.

Fotheringham, A.S. 1983: A new set of spatial-interaction models: The theory of competing destinations. Environment and planning A 15-1. DOI: http://dx.doi.org/10.1068/a150015

Gunn, C. A. 1994: Tourism planning basic concepts cases. Washington.

Hall, C. M. 2010: Spatial analysis: A critical tool for tourism geographies. Space place and tourism new perspectives in tourism geographies. London.

Hall, C. M. 1991: Introduction to tourism in Australia: impacts, planning and development. Melbourne.

Houston, D. B. 1967: The shift and share analysis of regional growth: a critique. Bulletin of Economics and Statistics 15-1. DOI: http://dx.doi.org/10.1111/j.1468-0084.1989.mp51001002.x

Internet 1: http://epp.eurostat.ec.europa.eu/portal/page/portal/eurostat/home (15.6.2013).

Internet 2: http://www.espon.eu/main/Menu_Publications/Menu_TerritorialObservations/trendsinaccessibility.html (15.6.2013).

Inskeep, E. 1991: Tourism Planning. An integrated and sustainable approach. New York.

Knowles, R. 1993: Research agendas for transport geography in 1990s. Journal of Transport Geography 1-1. DOI: http://dx.doi.org/10.1016/0966-6923(93)90033-V

Makrí, M. B. 2001: Accessibility Indices. A tool for comprehensive landuuse planning, Lund.

Page, S. 1994: Transport for Tourism. London.

Page, S. 1999: Transport and Tourism. New York.

Page, S. 2005: Transport and Tourism: Global Perspectives. Harlow.

Pearce, D. 1989: Tourist development. New York.

Prideaux, B. 1993: Possible effects of new transport technologies in the tourist industry in the 21st century. Brisbane.

Robbins, D., Thompson, K. 2007: Special issue on transport at tourist destinations. Journal of transport geography 15-2. DOI: 10.1016/j.jtrangeo.2006.12.001

Stevens, B. H., Craig, L. M. 1980: A critical review of the literature on shift-share as a forecasting technique. Journal of Regional Science 20-4. DOI: http://dx.doi.org/10.1111/j.1467-9787.1980.tb00660.x

Thompson, K., Schofield, P. 2007: An investigation of the relationship between public transport perfomance and destination satisfaction. Journal of transport geography 15-2. DOI: 10.1016/j.jtrangeo.2006.11.004.

Thurot, J. M. 1980: Capacité de charge et production touristique. Aix-en-Provance.

Todorovic, M., Bjeljac, Z. 2009: rural tourism in serbia as a concept of development in undeveloped regions. Acta geographica Slovenica 49-2. DOI: http://dx.doi.org/10.3986/AGS49208

Topole, M. 2009: Potential for tourism in the demographically threatened region of Jurklošter. Acta geographica Slovenica 49-1. DOI: http://dx.doi.org/10.3986/AGS49104

Tóth, G. 2002: Kísérlet autópályáink területfejlesztő hatásának bemutatására. Területi Statisztika 42-6. Budapest.

Veres, L., Abonyiné Palotás J., Csapó J., Darabos F., Huszti Z., Lampertné Akócsi I, Raffay Z., Talabos I., Veres L. 2011: Turizmus és közlekedés. Pécsi Tudományegyetem. Pécs. 